brazilianpoliticalsciencereview

ART I CLE

\title{
The World Cup and Presidential Popularity in Brazil*
}

\author{
Pedro Santos Mundim \\ https://orcid.org/0000-0002-7537-5152 \\ Universidade Federal de Goiás, Goiânia, Goiás, Brazil \\ Gleice Meire Almeida da Silva \\ https://orcid.org/0000-0002-5641-1920 \\ Universidade Federal de Goiás, Goiânia, Goiás, Brazil
}

From the political point of view, major sporting events are seen as a way of strengthening a country's institutional image and, as a result, the popularity of its leaders. Events in Brazil in response to the 2014 World Cup, however, point towards other conclusions. The objective of this article is to analyze the relationship between public opinion and the World Cup in Brazil with reference to data from quantitative and qualitative opinion polls conducted by the Office of the Secretary of Communication of the Presidency of the Republic. These analyses suggest that an increasingly critical view on the part of citizens as well as frustration with expectations vis-à-vis essential public services such as health and education had a direct impact on Brazilians' views of the event and their (dis)approval of the Federal Government. Amid a series of demonstrations in 2013 and 2014, the World Cup was transformed from a classic case of bread and circuses into a catalyst for popular dissatisfaction. Instead of a popularity boost and a smooth path to re-election in 2014, Brazilian political leaders found themselves scrambling to deal with the legacy of a World Cup own goal.

Keywords: World Cup; presidential popularity; public opinion; critical citizens; 2014 elections.

http://dx.doi.org/10.1590/1981-3821201900030001

For data replication, see https://doi.org/10.7910/DVN/XS9HSO

This publication is registered under a CC-BY Licence.

*Previous versions of this article were presented in the $11^{\text {th }}$ Meeting of the Brazilian Association of Political Science (ABCP) in Curitiba in 2018 and the $9^{\text {th }}$ Latin American Conference of Political Science (ALACIP) in Montevideo in 2017. We would like to express gratitude for the criticisms and suggestions received in these events. We also grateful to Wladimir G. Gramacho and the members of the team at the Advisory Council of Public Opinion Research (SECOM-PR) that worked on projects related to the 2014 World Cup. Finally, we would like to express our thanks to the criticisms and suggestions that we received from three anonymous reviewers for the BPSR. Any errors remaining are our responsibility. 
W hy do rulers risk their political capital by investing in and supporting the staging of sporting mega-events such as the World Cup and the Olympic Games, whose results, in terms of popularity, can be controversial? Even though the relationship between sports and politics is old, (BONDE, 2009; GUTTMANN, 2003; SIGOLI and DE ROSE JUNIOR, 2004; VINOKUR, 1988), this question is new for both political science in general (GIFT and MINER, 2017) and studies of public opinion and presidential popularity, more specifically.

Initially, there are several strategic reasons why rulers decide to invest in holding sporting mega-events. Hosting a World Cup or the Olympics entails investing public money in the construction and renovation of stadiums, Olympic installations, and possible improvements in the host cities, among other things. These initiatives tend to generate jobs and promote economic growth ${ }^{1}$. There is a large body of research about presidential popularity and vote choice that shows how improving the economy brings political rewards (BERLEMANN and ENKELMANN, 2014; LEWIS-BECK and STEGMAIER, 2013; NANNESTAD and PALDAM, 1994).

Countries that are seeking more international prestige and prominence see, in the successful staging of sporting mega-events, an opportunity to broaden their influence in the international arena (GRIX and HOULIHAN, 2013). To some degree, these policies are associated with discourses of political integration and the appreciation of national identity (ARNAUD, 1998). In Latin America, for example, authoritarian governments such as those of Getúlio Vargas (1930-1945) in Brazil, and Juan Domingos Perón (1946-1955) in Argentina, sought to re-affirm cohesion, national identity, and the values of the nationstate, and consequently advertise the regime, in sporting events (DRUMOND, 2009).

In Brazil, where presidential election years coincide with the World Cup, the political folklore is that one's chances of re-election could be related to the performance of the national soccer team. Even though there is no empirical support for this vision, Healy, Malhotra, and Mo (2010) showed that the performance of local sport teams was indeed capable of adding votes to incumbents and even voters' evaluations of presidents. For any government, it is best to contest elections with an electorate that

\footnotetext{
${ }^{1}$ Unfortunately, as can be seen in countries such as Brazil and South Africa, we now know that enormous public expenditures on these events are less than the benefits generated, which opens paths for large corruption schemes that involve politicians, businessmen, and contractors (COTTLE, 2011, 2014).
} 
is satisfied because of victories than it is to contest them with an electorate that is dissatisfied because of defeats.

Regardless of which of these reasons is most important, behind them is the idea that sports are capable of anesthetizing citizens' criticisms and working an as efficient tool for manipulating hearts and minds in favor of rulers. The political impacts of the World Cup held in Brazil, however, suggest a different scenario.

On October 30, 2007, Brazil was chosen as the host country of the FIFA World Cup of soccer. At the time, the news was very much celebrated and it also coincided with other positive data. The Brazilian economy was thriving, growing more than 6\%. Ex-President Lula (PT) had an approval rating of more than $60 \%$. Brazil was seeking more prestige and international influence. It was a moment of euphoria for Brazilians, who held high expectations for the future.

In November 2008, according to the Datafolha polling institute, $79 \%$ of Brazilians were in favor of holding the World Cup in Brazil; only 10\% were against it ${ }^{2}$. If these perspectives had persisted until 2014, and the Brazilian national team had ended up winning the tournament, it would have been a perfect scenario for any incumbent.

Yet a year before the World Cup, the perspective was less optimistic. Brazil had gone through a notable event: the protests of June 2013, which occurred during the Confederations Cup - a tournament staged as preparation for the World Cup. This tournament had witnessed the emergence of criticism and popular participation to a degree seldom seen in the recent political history of Brazil, and it had spread to various capitals and cities in Brazil.

Even if they were not the main reasons bringing people out to the streets (BRINGEL and PLEYERS, 2015; SINGER, 2013), the World Cup and its legacies, from then on, were called strongly into question. The protests continued to occur between 2013 and 2014 in various Brazilian cities. In them, "protesters carried banners shouted, 'Não vai ter copa!' - 'There will be no World Cup!'—and 'Copa para quem?!'-'World Cup for whom?' - with regularity to publicly question the logic of

\footnotetext{
${ }^{2}$ Available at: <http://media.folha.uol.com.br/datafolha/2014/06/10/copa-do-mundo-versaopara-o-site.pdf $>$. Accessed on: January, 03, 2019.
} 
spending on stadiums while the glaring inadequacies of transportation, health, and education systems continued to be neglected" (BAILEY et al., 2017, p. 80).

These protests brought to light a "list of grievances" (BAILEY et al., 2017, p. 80) and affected the support for the World Cup. By the end of June 2013, 65\% of Brazilians were in favor of holding the event in Brazil, and 26\% were against. In June 2014, support would fall to 51\%, with $35 \%$ against it ${ }^{3}$. This disgust also claimed an important victim: ex-President Dilma Rousseff (PT). In 2013, in less than a month, without any other important political or economic events having occurred, the percentage of respondents saying she was doing a good or excellent job went from $57 \%$ to $30 \%$, while the percentage saying she was doing a bad or terrible job went from $9 \%$ to $25 \%$. In June 2014, on the eve of the World Cup, her positive evaluation was at $33 \%$ and her negative evaluation was at $28 \% 4$.

Such events were in consonance with the results of recent studies about the perception of public opinion in regards to the legacy of sporting mega-events for residents of host countries. The promises made by rulers about the financial returns of public investments, increases in tourism, and improvements in the image of the country, among other things, do not always come to pass. They are also not necessarily perceived positively by people, even if local teams and athletes obtain good sporting results (BOYKOFF and FUSSEY, 2014; BUROCCO, 2014; COTTLE, 2011; DOMINGUES, BETARELLI JR. and MAGALHÃES, 2011; KIM, GURSOY, and LEE, 2006).

This is the context in which the question asked at the beginning of the article becomes pertinent. The political dimension of sporting mega-events is frequently addressed as a historical narrative (DRUMOND, 2009; GUTTMANN, 2003; SIGOLI and DE ROSE JR., 2004) or as a factor that generates tensions and social conflicts (BOYKOFF, 2011a, 2011b; BOYKOFF and FUSSEY, 2014). We do not know, however, of any 'typical' case study (GERRING, 2007) that has empirically established the relationship between support for sporting mega-events and presidential popularity 5 .

\footnotetext{
3Idem.

${ }^{4}$ Available at: < http://media.folha.uol.com.br/datafolha/2014/06/06/intencao-de-votopresidente-2014.pdf>. Accessed on: January, 07, 2019.

${ }^{5}$ We understand that the relationship between the 2014 World Cup and presidential popularity in Brazil is a typical case study because: 01 . it is a typical example of the relationship between a
} 
In the first part of this article, we discuss the literature on presidential popularity. We emphasize the political dimension of what has become known as the VP, or vote and popularity, function. Next, we argue that sporting mega-events can be included in models to explain the determinants of popularity for rulers through categorizing the 2014 World Cup as a 'rally event' that impacted the evaluation of the Brazilian federal government ${ }^{6}$.

In the second part, we present the data used in this study: a national public opinion poll and focus groups held in all the host cities of the tournament. They were conducted by the Brazilian President's Secretariat of Social Communication's Advisory Council of Public Opinion Research (SECOM-PR) between March and June 2014. They sought to analyze Brazilians' support for and evaluations of the 2014 World Cup. These studies also measured opinions about the federal government, public services, and Brazil's economy, among other things, which allows us to study in detail the relationship between the World Cup and the federal government.

Generally, the analyses we conducted showed an increase in citizens' criticism of essential public services, such as health and education, as well as their frustration with future expectations for them. This directly impacted Brazilians' visions of the World Cup and their approval of the federal government. The World Cup worked as more of a simple filter through which the population began to evaluate the supply of public services and presidential management. It went from the idea of 'the opium of the people' to a catalyzing symbol of the population's dissatisfaction. Instead of increasing popularity and facilitating electoral gains in 2014, the World Cup put Brazilian political leaders' political capital at risk.

\section{The VP function: the P part and its political determinants}

Based on 25 years of literature about the relationship between public support for the government and the vote, Nannestad and Paldam (1994, p.

sporting mega-event and the approval rating of a government, or of the variables that measure this correlation; 02 . our objective is precisely that of implementing a hypothesis test to confirm this association; and 03. it is representative of this type of political phenomenon.

${ }^{6}$ Another important note is that, up to now, there are few Latin American studies on the VP function and presidential popularity that have studied rally events. With the exception of Peruvian studies that included the capture of the leader of the Shining Path in their models (KELLY, 2003; MOISÉS, 2003; MOISÉS and CARRIÓN, 2010), we know little about the type of effects from rally events that are important for Latin American public opinion and incumbents. We would like to thank one of the anonymous reviewers from this journal for drawing our attention to this fact. 
214) summarized the VP function, where V represents the vote and $P$ popularity. The studies they reviewed showed that these two dimensions are influenced by economic (E) and political (P) variables; that is, by changes in the economy and in politics.

Indices of presidential approval are based on measures of how much the population approves of the performance of the government as a whole, and of the president in particular. These ratings are affected by gains in the political image of the president. Popularity is therefore a thermometer for knowing how the public is thinking about the direction of the government, and consequently, how they are likely to vote in the elections (BERLEMANN and ENKELMANN, 2014)7

As with most of the studies we analyzed, Nanestad and Paldam's (1994) explanations are focused on the economic part of the function, inspired mainly by the theory of the economic vote; voters put responsibility for economic conditions on presidents, and this is reflected in the vote (FIORINA, 1981; KIEWIET, 1983; KINDER, 1981; LEWIS-BECK and STEGMAIER, 2013). In other words, the attribution of responsibility is a crucial factor.

Even though it supplies elements that make a general understanding of the variables that impact popularity easier, the VP function, with its emphasis on the economic dimension, is insufficient for explaining the relationship between the World Cup and the federal government. It is important to note that in 2014, even with demonstrations of the deterioration of the economic model and retractions in consumption, Brazil's economy still was not a reason to worry for most Brazilians. Furthermore, in electoral years, governments make an effort to minimize any sign of possible economic crisis (BORSANI, 2001). Nannestad and Paldam (1994) emphasize that the rule of responsibility, which occurs on the economic part of the equation, is not valid for political variables because they are defined qualitatively and asymmetrically. This makes it more difficult to insert them in the models. As a result, we do not dive into the wide field of discussion about economic determinants in depth, even though it is without doubt the topic most often explored in the literature. We will invest our efforts into understanding the variants of popularity on the political part.

\footnotetext{
${ }^{7}$ In this article, we do not deal with the vote directly, but we do deal directly with popularity, although the literature about the vote and popularity are interconnected and often confused.
} 
In accordance with Berlemann and Enkleman (2014), since Muller's seminal study (1970), the 'non-economic' studies have been divided into those with variables related to the personal characteristics of the president, her time in office and the honeymoon period; variables related to wars; and variables related to events. Just one genuine political variable, however, has been used frequently, argue Nannestad and Paldam (1994): the rally-round-the-flag effect. Most of these studies, mainly American, focus on the temporary patriotic effect caused by news about wars or imminent conflicts, and the positions on the international plane that exercise a temporary positive impact on the image of the head of state.

According to Muller (1970), for a rally-round-the-flag effect to exist, there needs to be some sort of crisis in foreign policy that directly involves the figure of the president and entails a political drama. Not all rally events, however, have the patriotic rally-round-the-flag effect. As Berlemann and Enckleman (2014) suggested, specific and important events such as the Watergate affair, John F. Kennedy's assassination, or the September 11 attacks, are all capable of having a sudden impact on presidential approval ratings.

In the wake of this new understanding, the idea of rally events has been broadened to include domestic events (not only international events) and events that that negatively impact presidential approval ratings (not just those that positively affect it and involve patriotism) (OSTROM JR. and SIMON, 1985, 1989). There is, however, a difference in how researchers include these events in their approval rating models. The criteria of choice are not standardized because rally events include criteria such as the specificity and dramatic relevance of the event and subjective choices stemming from the space and time dedicated to the political coverage of the event.

Regarding the most important differences, Newman and Forcehimes (2010) compiled a list of historical events already identified by other researchers as typical rally events. They looked for common selection criteria in the consolidated literature on the subject, using both Muller's initial proposal (1970), which argued that rally events should be international, dramatic, and should directly involve the figure of the president, and the later theoretical refinements of Kernell (1978), and Ostrom Jr. and Simon $(1985,1989)$ to also 
include domestic events with space in the media whose impacts could make presidential popularity either increase or decrease.

Another important contribution from Newman and Forcehimes (2010) was an emphasis on the media's capacity to impact the relationship between public opinion and the government (EDWARDS III, MITCHELL and WELCH, 1995; KROSNICK and BRANNON, 1993; KROSNICK and KINDER, 1990; MUTZ, 1994; NADEAU et al., 1999). To be a rally event, it is essential for there to be widespread media attention, and for the event to be in the news for a considerable amount of time. That is, it is necessary to break people's 'attention threshold' for them to begin to consider a given event important or relevant (OSTROM JR. and SIMON, 1985) ${ }^{8}$. If not, the topic at hand will not have enough force to alter evaluations of performance. Since these events have an impact on approval ratings, omitting them would lead to mis-specified popularity functions.

The last selection criterion for events was therefore the importance given by the media to the topic. In their study, Newman and Forcehimes (2010) summarized the perspectives of several authors in a list of 120 historical events between 1953 and 2006 that fit the standardized selection criteria ${ }^{9}$. The results of the tests that they implemented showed that certain events and facts, as rally events-that is, as dramatic, domestic, or international events-really were capable of positively or negatively impacting presidents' popularity over the time period they analyzed.

\section{The World Cup as a rally event}

Initially, sporting mega-events did not fit into the rally event category. The World Cup, for instance, was a project that was predictable, planned, and drawn up. Positive results were expected, which would have increased the rulers'

\footnotetext{
${ }^{8}$ This discussion about 'thresholds' is not new, and is present in Downs (1999), even though it was not fully developed by him. For a criticism, but also an attempt to reformulate and apply the concept of thresholds to politics and political advertisement, see NOLL (1995).

${ }^{9}$ Among the 120 events selected by Newman and Forcehimes (2010) are, for example, the death of the newborn son of John F. Kennedy in August 1963, the outbreak of violence in big U.S. cities in August 1967, the peak of anti-war protests in November 1969, the cease-fire in Vietnam in February 1973, and the student protests in May 1968.
} 
popularity. Between the selection of Brazil as the tournament venue and the tournament's staging, however, there was a series of factors that turned this predictability upside-down, allowing for this sporting mega-event to become a rally event.

Sporting mega-events nowadays are connected to the intense circulation of money, worldwide visibility, considerable revenue for the mass media and private enterprises, political capital, and especially, the population's desire for social advances in infrastructure and urbanization (PENNA, 2013). For this reason, the public discourse in favor of hosting these events always contains promises about the tournament's legacy, which will remain afterwards for the citizens residing in the host cities (ALMEIDA et al., 2015). This therefore creates a relationship of expectations versus the delivery of the service, or between the expectation created and the perception of what is actually received.

Studies on the perception of sporting mega-events' legacies indicate that a series of factors mediates this relationship. Prayag et al. (2013) showed that residents' support is not motivated uniformly by the same questions, but rather influenced by different perceptions of socio-cultural, environmental, and economic impacts, both positive and negative. Ritchie et al. (2010) emphasize the role of the media in forming perceptions about tournaments. Kim and Petrick (2005) and Waitt (2003) point out that feelings of enthusiasm tend to cool off over time, reducing the public's confidence in the events. In all these approaches, it is clear that the bundle of promises made in order to host the events can often come into conflict with the legacy that is actually left in practice. In the Brazilian case, expectations were formed well before preparations began, going beyond the specific legacy of the event to include promises of better quality of life in various areas, especially infrastructure, within a model of rising development. As a result, understanding the relationship between the 2014 World Cup and the evaluation of the federal government is impossible without considering the events that happened before it was held, especially the protests of June 2013 (when the Confederations Cup, the preparatory tournament for the World Cup, was held in Brazil) and the protests that followed in 2014.

The graphs in Figure 01 reinforce this line of reasoning. They bring the monthly evolution of Dilma Rousseff's approval rating, news coverage about Brazil, 
and support for the World Cup in Brazil. In regard to the ex-President's popularity, although it took a small hit between March and June 2013, the most important reverse happened after the intensification of the protests that took over the country during the Confederations Cup. The visibility that they gained certainly encouraged more critical attitudes, which led to an increase in protests throughout Brazil, as the graphs on news coverage in 2014 show, and a loss of prestige on the part of the FIFA World Cup. This shows that sporting mega-events, with all their potential visibility, can bring risks in terms of political capital.

Figure 01. Monthly approval of ex-President Dilma Rousseff, retrospectives of the main news coverage in Brazil by week, and support for holding the 2014 World Cup in Brazil
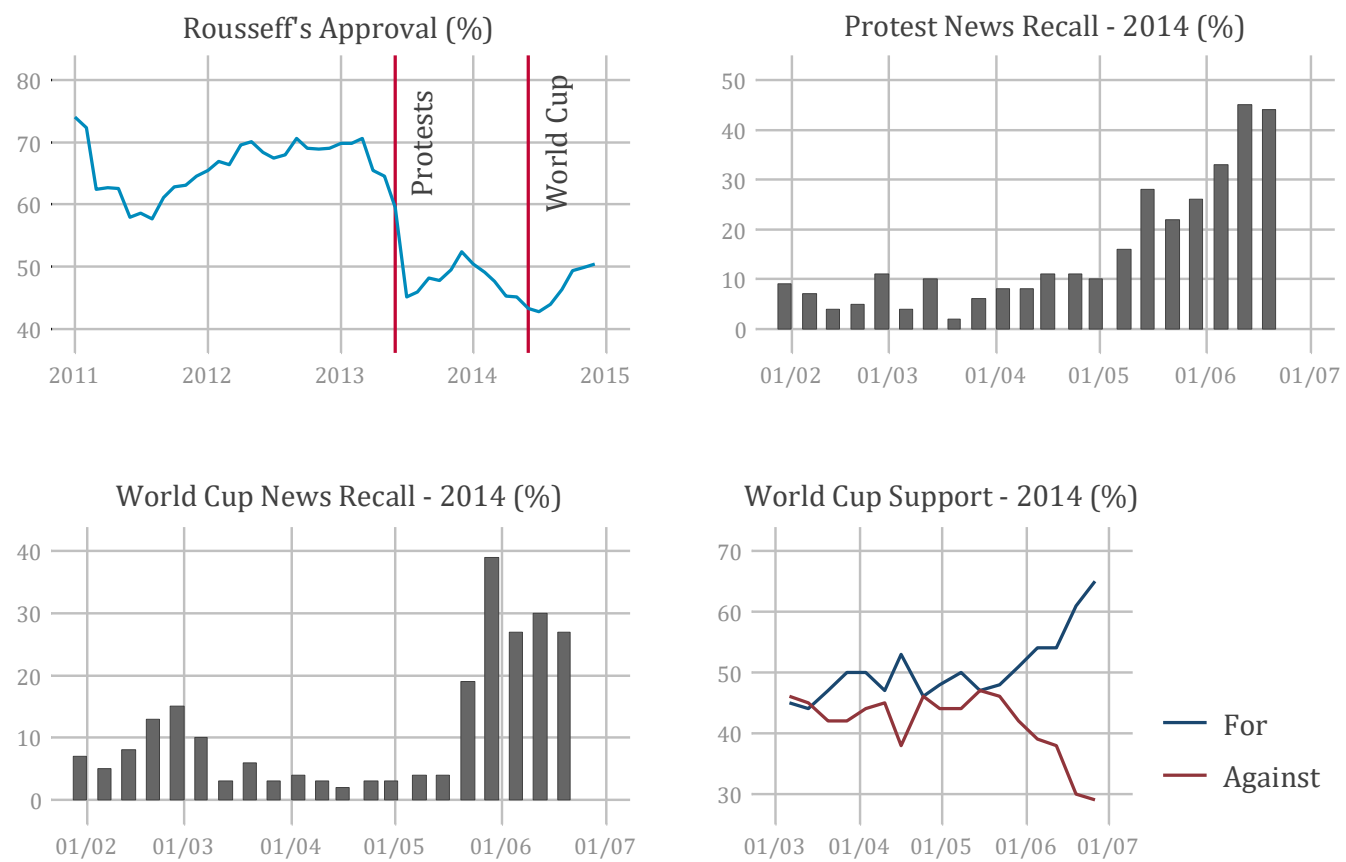

Source: Executive Approval Project (CARLIN et al., 2016) and Weekly Telephone Surveys from Secom/PR - 2014.

According to Newman and Forcehimes (2010), rally events can have negative impacts on presidents' approval, as is the case with scandals, social unrest, and unpopular initiatives. In this sense, the 'Cup of Protests', as it became known, and the other protests that followed, were a category that the specialized literature calls rally events. These events put the FIFA World Cup definitively on the radar of the press, the federal government, and Brazilian public opinion. They 
were inserted into a special context insofar as they began to channel various popular dissatisfactions and resentments that were expressed, for example, in the requirements for 'FIFA-standard public services', and draw attention to the country's problems (BAILEY et al., 2017). The transition of the mega-event, expected to be the 'opium of the people', into the trigger for protests conferred a degree of surprise upon the tournament, which began to embody a political drama and a factor of social unrest, becoming confused with other hot-button issues from the popular protests.

Our hypothesis, therefore, is that the 2014 World Cup generated a negative rally effect on presidential popularity. It became, as such, a shortcut that citizens began to use to express criticism of the management of the federal government. This occurred because there was, at that moment, a certain distance between the high expectations for the supply of public services and the perception of what was effectively delivered, accompanied by reports of corruption and abuses of public resource expenditures for the construction of stadiums that would be the site of World Cup games.

\section{Description of the data}

Our argument that the World Cup could be seen as a rally event has points in common with studies about the political use of sports. We assume that the evaluation of sporting mega-events is correlated with the popularity of political leaders, and that this association is positive, with the causal relationship mainly flowing from the evaluation of the event to the evaluation of the government. As the Brazilian case shows, however, sporting mega-events do not always help popularity; in other words, their political use can be an ineffective strategy.

The analyses we implement in these articles seek to clarify these points. We seek to determine above all if there is, in fact, a positive correlation between the approval of the federal government and opinions about holding the World Cup in Brazil. Our expectation was that the response to this question would be positive. We adopted the strategy of implementing, first of all, a multi-variate analysis with national public opinion polling data with the objective of testing if the theoretical premises we presented found empirical support through rigorous tests. The second step was to work with qualitative data from focus groups in order to get both a 
better understanding of the causal relationships found between some variables from the models we estimated and a deeper understanding of these interpretations.

The polls used in this study were conducted by Ibope Inteligência (Ibope Intelligence) and the Instituto Análise (Analysis Institute) upon request from Secom/PR. We worked with a face-to-face household study with a national sample of 2002 interviews that was conducted March 22-27, 2014 with a margin of error of $\pm 2.2 \%$ and a confidence interval of $95 \%{ }^{10}$. We also analyzed the transcripts of 88 focus groups held between 2013 and 2014, that were made up of people 18 years and older of both sexes, all socioeconomic classes (A, B, C, and D), and residents of World Cup host cities ${ }^{11}$.

In the statistical analysis, the dependent variable was the binary indicator of approval of the federal government. At the time, approval was at $49 \%$ and rejection at $45 \%{ }^{12}$. The independent variables were divided into three groups: 01. those related to the World Cup; 02. those related to the economy and public services; and 03. socio-demographic variables. Respondents were asked if they were 'in favor of or against holding the World Cup in Brazil' and if 'holding the World Cup in Brazil would bring more benefit or more harm to the country'. In the first case, the possible responses only allowed for the construction of a binary indicator of support for the event. In the second case, we opted to include the possibility of a neutral response ('will neither benefit nor harm') as a reference category. We also looked to evaluate the level of interest and enthusiasm for the FIFA World Cup through a question about the number of games that the respondent intended to watch, as well as delimiting whether the respondent lived in a host city or not.

\footnotetext{
${ }^{10}$ The selection of the sample was probabilistic in two stages: a PPS method in the first stage (Probability Proportional to Size) through telephone numbers and quotas of sex, age, education, and line of business in the second stage. The questionnaire of the poll is available on the Secom/PR website. The database can be requested through Secom's office of public opinion research, or through Secom/PR itself.

${ }^{11}$ There were four waves of qualitative studies: 01. World Cup Qualitative Study I (September, 2013); World Cup Qualitative Study II (October, 2013); Pre-World Cup Qualitative Study (April, 2014); and 04. Qualitative Study on the Climate of the World Cup (June, 2014). The script in the groups and the reports on the studies are available on Secom/PR's website. The transcripts of the focus groups can be requested through Secom's office of public opinion research, or through Secom/PR itself.

${ }^{12}$ Secom/PR's studies are institutional, not personal or partisan. Therefore, mentioning any political figure or party-including the President-is forbidden. This is why the term of 'federal government' is Always used. This prohibition also limits, however, the topics that could be explored in the questionnaires, which should conform to questions linked to the actions of communication of the public administration (GRAMACHO, 2014).
} 
The inclusion of variables about the economy and public services looked to bring our analysis closer to the canonical studies on presidential popularity. As shown in the theoretical part of the article, they tend to privilege the economic dimension and the evaluation of public policies as explanatory factors. The socio-demographic variables were included as controls for contextual and individual effects associated with the main variables of interest. We believe that whatever analysis without the presence of these indicators would lead to the misspecification of the model.

Table 01 shows the format and the descriptive statistics of these variables and the indicators of Groups 02 and 03 . The formats are self-explanatory except for the measure of corruption as the biggest problem of the country, which was constructed through a question that looked to measure the area in which the Brazilian population confronted the largest problems at the time. Since up to three responses were possible, we created a binary variable to measure if the respondent mentioned corruption in any one of them.

Table 01. Format and description of variables used

\begin{tabular}{|c|c|c|}
\hline Variable & Mean & $\begin{array}{l}\text { Std. } \\
\text { Error }\end{array}$ \\
\hline Approval of the federal government & 0.52 & 0.50 \\
\hline \multicolumn{3}{|l|}{ 01. World Cup } \\
\hline Approval of the World Cup (in favor of holding it in Brazil) & 0.59 & 0.49 \\
\hline Legacy (more benefit) & 0.33 & 0.47 \\
\hline Legacy (more harm) & 0.42 & 0.49 \\
\hline Host city (both capital and periphery) & 0.39 & 0.49 \\
\hline Interest in watching games (no game, only Brazil's games, every game) & 2.25 & 0.76 \\
\hline \multicolumn{3}{|l|}{ 02. The economy and public services } \\
\hline $\begin{array}{l}\text { Evaluation of the economic situation of the country (terrible, bad, fair, } \\
\text { good, excellent) }\end{array}$ & 2.91 & 0.95 \\
\hline $\begin{array}{l}\text { Evaluation of their personal economic situation (terrible, bad, fair, good, } \\
\text { excellent) }\end{array}$ & 3.24 & 0.89 \\
\hline Evaluation of public services (0-10) & 4.91 & 2.46 \\
\hline Corruption (biggest problem for the country) & 0.28 & 0.45 \\
\hline \multicolumn{3}{|l|}{ 03. Socio-demographic } \\
\hline Sex (Male) & 0.48 & 0.50 \\
\hline Age $(16-24,25-34,35-44,45-54,>55)$ & 3.01 & 1.42 \\
\hline $\begin{array}{l}\text { Education (no formal education, up to } 4 \text { th } \text { grade, } 5^{\text {th }}-8^{\text {th }} \text { grade, high } \\
\text { school, college) }\end{array}$ & 3.36 & 1.11 \\
\hline $\begin{array}{l}\text { Monthly Family income (up to } 1 \text { minimum wage, } 1-2 \text { minimum wages, } \\
2-5 \text { minimum wages, and }>5 \text { minimum wages) }\end{array}$ & 2.55 & 0.88 \\
\hline $\begin{array}{l}\text { Size of the city (up to } 20,000 \text { inhabitants, } 20,000-50,000,50,000- \\
100,000,100,000-500,000,>500,000 \text { ) }\end{array}$ & 3.55 & 1.41 \\
\hline
\end{tabular}

Source: Quarterly Public Opinion Poll (2014), Secom/PR - March 2014. 


\section{The World Cup and the Federal Government}

We estimated binary logistic models in order to analyze the correlations between the descriptive variables in Table 01 with presidential popularity ${ }^{13}$. The main expectation was that we would find an association between the variables linked to the World Cup and the approval rating of the federal government, controlling for various factors. We also expected that these indicators would be larger in host cities, as residents there would be those who would most feel, day-today, the positive and negative consequences of the tournament. They also concentrate on the main protests between 2013 and 2014. Starting from the idea that the World Cup worked as a shortcut though which citizens began to express criticisms of the government, we included an interaction term between being in favor of holding the World Cup and one's evaluation of public services ${ }^{14}$. Our results can be seen in Table 02 .

The data suggest that in March 2014, the World Cup influenced presidential popularity. One can use the data from Model 02, for example, to estimate that citizens who were in favor the World Cup had a 63\% (95\% CI=59\%, 67\%) chance of approving of the federal government, holding the values of all other variables at their means. Those who were against it had a $37 \%$ chance $(95 \% \mathrm{CI}=32 \%, 42 \%)$ of doing so. A third expectation that was confirmed was that living in a host city reduced the chances of approving of the government: $45 \%$ (95\% CI=40\%, 50\%) for residents against $57 \%(95 \% \mathrm{CI}=53 \%, 61 \%)$ for non-residents ${ }^{15}$.

The graphs in Figure 02, which show the probability of approving of the federal government as a function of one's support for the World Cup and evaluation of public services, illustrate the form of these interactions ${ }^{16}$. Among those who were in favor of holding the World Cup, for example, an increase in the grade given to public services substantially increased one's chances of approving of the federal government. At the same time, a reduction of that grade increased the chances of rejection. These estimates also suggested that this relationship mattered more in host cities, among them some cities in which the biggest and most frequent protests against the World Cup were held between 2013 and 2014.

\footnotetext{
13We also estimated a multinomial logistic model and an ordinal logistic model in order to access the impact of the variables described in Table 01 about the evaluation (good/excellent, fair, bad/terrible) of the federal government. The results show no substantive differences.

${ }^{14}$ To build this interactive term, we 'centralized' the variable of the evaluation of public services on its mean.

${ }^{15}$ We used the 'margins' command in STATA to estimate the precited probabilities mentioned in the text and in the graphs in Figure 02 (WILLIAMS, 2012).

${ }^{16}$ To generate the graphs, we estimated Model 02 only with the variables that reached statistical significance.
} 
Table 02. Determinants of approval of the federal government

\begin{tabular}{|c|c|c|c|}
\hline & (1) & $(2)$ & (3) \\
\hline \multirow{2}{*}{ Economic evaluation of the country } & $2.22^{* * *}$ & $2.23^{* * *}$ & $2.24^{* * *}$ \\
\hline & $(0.16)$ & $(0.17)$ & $(0.17)$ \\
\hline \multirow{2}{*}{ Personal economic evaluation } & $1.15^{*}$ & 1.12 & 1.12 \\
\hline & $(0.08)$ & $(0.08)$ & $(0.08)$ \\
\hline \multirow{2}{*}{ Evaluation of public services } & $1.21^{* * *}$ & $1.17^{* * *}$ & 1.07 \\
\hline & $(0.03)$ & $(0.03)$ & $(0.04)$ \\
\hline \multirow{2}{*}{ Corruption } & 0.90 & 0.89 & 0.89 \\
\hline & $(0.11)$ & $(0.12)$ & $(0.12)$ \\
\hline \multirow{2}{*}{ Man } & 0.89 & 0.83 & 0.82 \\
\hline & $(0.10)$ & $(0.10)$ & $(0.10)$ \\
\hline \multirow{2}{*}{ Age } & 1.00 & 1.01 & 1.01 \\
\hline & $(0.00)$ & $(0.00)$ & $(0.00)$ \\
\hline \multirow{2}{*}{ Education } & $0.80^{* * *}$ & $0.84^{* *}$ & $0.84^{* * *}$ \\
\hline & $(0.05)$ & $(0.06)$ & $(0.06)$ \\
\hline \multirow{2}{*}{ Personal income } & 0.93 & 0.98 & 0.99 \\
\hline & $(0.07)$ & $(0.08)$ & $(0.08)$ \\
\hline \multirow{2}{*}{ Size of city } & $0.84^{* * *}$ & $0.90^{* *}$ & $0.90^{* *}$ \\
\hline & $(0.03)$ & $(0.04)$ & $(0.04)$ \\
\hline \multirow{2}{*}{ Support for the World Cup (in favor) } & - & $2.89^{* * *}$ & $2.74^{* * *}$ \\
\hline & - & $(0.49)$ & $(0.53)$ \\
\hline \multirow{2}{*}{ Interest in the World Cup } & - & 1.02 & 1.01 \\
\hline & - & $(0.09)$ & $(0.09)$ \\
\hline \multirow{2}{*}{ Host city } & - & $0.62^{* * *}$ & $0.56^{* * *}$ \\
\hline & - & $(0.08)$ & $(0.11)$ \\
\hline \multirow{2}{*}{ Benefit } & - & 1.21 & 1.20 \\
\hline & - & $(0.20)$ & $(0.20)$ \\
\hline \multirow{2}{*}{ Harm } & - & 1.12 & 1.13 \\
\hline & - & $(0.20)$ & $(0.20)$ \\
\hline \multirow{2}{*}{ Support for the World Cup (in favor) $\times$ Host city } & - & - & 1.19 \\
\hline & - & - & $(0.30)$ \\
\hline \multirow{2}{*}{ Support for the World Cup (in favor) $\times$ Public services } & - & - & $1.15^{* *}$ \\
\hline & - & - & $(0.07)$ \\
\hline \multirow{2}{*}{ Support for the World Cup (in favor) $\times$ Host city $\times$ Public services } & - & - & 1.03 \\
\hline & - & - & $(0.08)$ \\
\hline $\mathrm{N}$ & 1744 & 1601 & 1601 \\
\hline Pseudo R2 & 0.179 & 0.222 & 0.226 \\
\hline Log lik. & -989.4 & -862.3 & -858.0 \\
\hline Chi2 & 432.6 & 491.2 & 499.8 \\
\hline AIC & 1998.9 & 1754.6 & 1751.9 \\
\hline
\end{tabular}

Source: Quarterly Public Opinion Poll (2014), Secom/PR - March 2014. Notes: The coefficients shown are the likelihood ratios. Standard errors in parentheses. ${ }^{* * *} \mathrm{p}<0.01 * *$ $\mathrm{p}<0.05^{*} \mathrm{p}<0.10$. 
Figure 02. Probability of approving of the federal government as a function of supporting the 2014 World Cup, the evaluation of public services, and the type of city
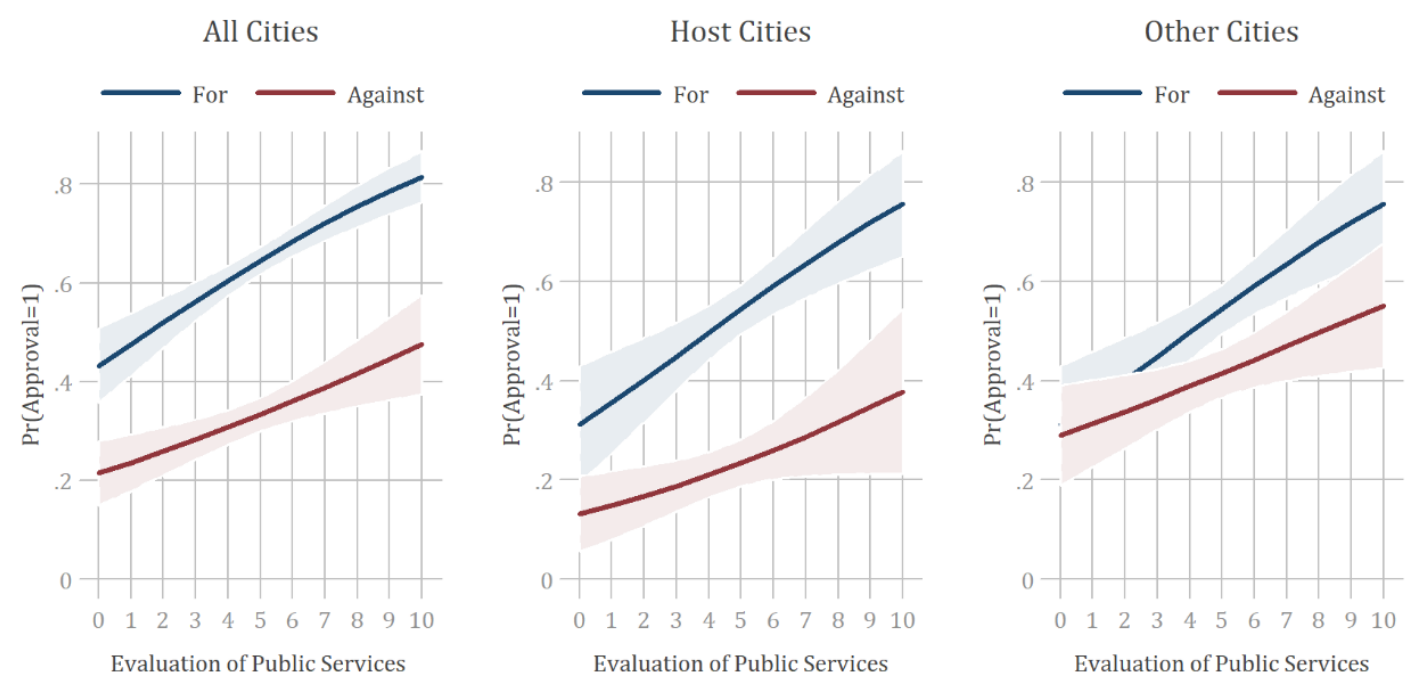

Source: Elaborated by the authors.

Holding the World Cup involved a series of decisions on the part of political actors, which could have re-activated and highlighted the importance of problems linked to public services in the heads of citizens. Since the evaluation of public services is an important component of evaluating governments, which affects their popularity, the existence of this network of correlations made the FIFA World Cup an indirect mechanism, or a shortcut, for the approval of the federal government. This clarifies a little bit more the mechanism through which the tournament affected presidential popularity and justifies this worry about President Rousseff's government and how the organization of the tournament would affect the evaluation of her term, especially in a year in which she would run for re-election.

One objection to these conclusions is that the popularity of the president might influence the positioning of citizens in regard to the World Cup. The data suggest that this could indeed be the case. We estimated a regression with the same variables that were included in Model 02; the difference was defining support for the World Cup as the dependent variable. The estimated impact on approval of the federal government on support for the World Cup $(\beta=1.055, p<.01)$ was similar to that of support for the World Cup on approval of the federal government $(\beta=1.062$, $p<.01$ ). Unfortunately, the quantitative analyses do not completely elucidate the 
most probable direction of causality, and there are no additional data that would allow us to solve this problem. The focus groups conducted by Secom/PR, however, help us with this task. Although we are aware of the limits of qualitative studies for inference and attributing causality (KING, KEOHANE and VERBA, 1994), we believe that, for the analyses implemented in this article, they are the most forceful data that we could use.

\section{The qualitative explanations}

Qualitative studies, such as focus groups, have the advantage of offering the perspective of the considerations that led to the formation of opinions (CHONG, 1993). We can more clearly see the worries running through Brazilians' heads about the World Cup, what types of spontaneous and stimulated associations were emphasized during the discussions, and how they thought and reasoned when encouraged to talk about the topic ${ }^{17}$. Although the material offers the richness of contextual information, its purpose was not to conduct an exhaustive analysis, mainly because they also dealt with other topics that interested the federal government. We sought to verify that the indications found in the quantitative analysis came close to the impressions of the public in the focus groups.

\section{The World Cup and protests: the visibility of the event}

From the Confederations Cup on, the 2014 World Cup began to be a source of pressure on the federal government. The criticisms of the expenditures on the mega-event only became stronger in the rhetoric of protesters given the precariousness of public services, the requirements for 'FIFA-standard' public services, the delays in construction projects, and the 'there will be no World Cup' refrain, which drew attention to the countless problems of the country. The discussions that emerged from the focus groups challenged the historicalsociological perspective of soccer as the 'opium of the people' in Brazil. The World

\footnotetext{
${ }^{17}$ It is worth emphasizing that, in addition to other criteria, the participants in the groups in 2013 were separated between those who evaluated the federal government as good/excellent, fair, and bad/terrible. The groups in 2014 were already divided by the criterion of approval of the World Cup. In the pre-World Cup wave, the groups were separated into those who approved and disapproved, and in the Climate of the World Cup wave, they were mixed together-in other words, 50\% approved and 50\% disapproved.
} 
Cup became a wake-up call for the masses, which was translated into the narrative behind the slogan that 'the giant has awakened' (FARIA, 2016). It was possible to find these associations in several quotations from the focus groups: "'Every fool has a moment in which he explodes'. Maybe the World Cup was just the peak for unmasking some things that led to an explosion. It is clear that everything in excess gets closer to an extreme that begins to stop making sense, but I think the essence of the thing is very pertinent. 'The World Cup was the trigger for the protests'" (our emphasis) (ANONYMOUS INTERVIEWEE , 201318)19. "'The protests were mainly generated by the expenditures of the World Cup' when there isn't enough money for other things" (our emphasis) (ANONYMOUS INTERVIEWEE, 201320).

From the Confederations Cup on, the visibility of the event began to be used as a way to apply pressure. Despite the majority's fondness for soccer, the public was willing to not only question the country's problems, but also to use the worldwide exposure of the World Cup to show that Brazil was not just a label for sports, but hid deep social problems as well.

"Before the protests, they [other countries] were sure about the image that they wanted to preach: that Brazil is a country that is more Carnival and soccer. 'But the protests changed that'" (our emphasis) (ANONYMOUS INTERVIEWEE , 201321).

"I think that it got better because the rulers listened to the population a little. 'It was the way that we found to get their attention'. A message was passed on to them" (our emphasis) (ANONYMOUS INTERVIEWEE, 201322).

If you think about the Brazilian World Cup, you see through the Confederations Cup that 'this patriotism created the protests that the whole world saw'. The points that they made were very valid. The World Cup in Germany cost $\$ 30$ million and this one in Brazil is costing more than $\$ 50$ million, with the German World Cup being awesome while here 'in Brazil there is still the big matter of a lack of infrastructure, airports, and public transportation'. And this extra money that is invested is probably being diverted at some point. Because it can't

\footnotetext{
${ }^{18}$ Natal, Copa II, AB, 19-25, good/excellent.

${ }^{19}$ In reference to the transcripts, in order to facilitate identification, what follows is the name of the city, the name of the study, the social classes, age group, gender (when there is one), evaluation of the government (when there is one) or the evaluation of the World Cup (when there is one). We would like to emphasize that the 2013 studies were not divided by gender into groups.

${ }^{20}$ Porto Alegre, Copa II, AB, 18-25, fair.

21Porto Alegre, Copa II, AB, 18-25, fair.

${ }^{22}$ Cuiabá, Copa II, CD, 18-25, bad/terrible.
} 
be so expensive and yet not have the quality that it has in other countries. 'This money could be spent on hospitals, rural hospitals, public transportation, to provide quality to society' (our emphasis) (ANONYMOUS INTERVIEWEE, 2013 ).

"It's a lot of money spent on stadiums and 'lots of people dying in lines at the hospital'" (our emphasis) (ANONYMOUS INTERVIEWEE , 201323).

That way, more than a trigger for a set of dissatisfactions, the World Cup began to be set up, at that initial moment, as a shortcut for evaluating the federal government. In all the discussion groups, without any exceptions, the spontaneous approaches of the participants in reference to the World Cup, without fail, mentioned questions about the product that they were receiving from government action in comparison to the investments for the World Cup.

\section{The World Cup and the government: the frustration of expectations, distrust, and who was responsible for it all}

When Brazil was chosen to host the World Cup, the climate was of optimism and excitement about the country and the event. After all, Brazil is recognized as the country of soccer (DAMATTA, 1986). This vision about hosting the World Cup, however, changed over the years between the decision to give the event to Brazil and the run-up to the actual event. The complexity of the organization, the expenses involved, the requirements of FIFA, and the distrust about the use of resources all seem to have provoked a change in the public's perception of the World Cup.

But why did Brazilian citizens begin to position themselves against the World Cup? The focus groups of the World Cup Climate study, conducted in June 2014 on the eve of the event, supplied a more refined vision of this matter. The following questions were included for respondents in the 12 host cities: 'When it was announced that Brazil was going to host the 2014 World Cup, were you in favor of or against holding the World Cup here?' Afterwards, respondents were asked, 'why did you change your opinion?' The goal of this question was precisely to determine how the participants described the emotional and cognitive processes they experienced during this period of time, with the main intuition of

\footnotetext{
23Porto Alegre, Copa II, CD 30-39, bad/terrible.
} 
untangling the causal relationship between support for the World Cup, evaluations of public services, and evaluations of the federal government.

"It changed. 'I was in favor of it because of my passion for it'. Because it was a dream, because of the parties, the happiness. But then came the realism. I think it was the prioritization of these mammoth works, 'which weren't as necessary as health and education'" (our emphasis) (ANONYMOUS INTERVIEWEE, 201324).

"I thought it was going to be a good thing for Brazil. But as it was approaching...approaching...I was seeing death, protests, strikes, lots of things happening, and then 'you go and become aware of it'." (our emphasis) (ANONYMOUS INTERVIEWEE, 201325).

"Because when it was announced, we thought "Now it's in Brazil, and all." It's just that we didn't stop to think that it would mess with the entire city, what they were going to do. We just thought about soccer, and the people coming here. What made us oppose it was the badly done works." (ANONYMOUS INTERVIEWEE, $\left.2013^{26}\right)$.

"I was in favor of it, I celebrated. Then lots of messes started to happenprotests, "they said that Brazil was going to improve and it didn't'. I became against it!" (our emphasis) (ANONYMOUS INTERVIEWEE, 201327).

"For me, they sold one story and it became another'" (our emphasis) (ANONYMOUS INTERVIEWEE, 201328).

"They said they would build at the time, but I 'thought they'd build a decent hospital, that they'd finish the basic hospitals, a decent hospital for the people', I thought that the police would be better, and unfortunately, we have to take advantage of that" (our emphasis) (ANONYMOUS INTERVIEWEE, 201329).

What the participants said suggest that the change in the perception of the event came from an awareness that the country would have to organize and foster, with public resources, the structure for holding the World Cup. The direction and management of the World Cup on the part of the government and its breaking of

\footnotetext{
${ }^{24}$ Belo Horizonte, World Cup Climate, AB, 35-50, female.

${ }^{25}$ Belo Horizonte, World Cup Climate, CD, 35-50, female.

${ }^{26}$ Belo Horizonte, World Cup Climate, CD, 35-50, female.

${ }^{27}$ São Paulo, World Cup Climate, CD, 35-50, male.

${ }^{28}$ São Paulo, World Cup Climate, CD, 35-50, male.

${ }^{29}$ Brasília, World Cup Climate, CD, 35-50, male.
} 
promises began, little by little, to be put to the test. The expectation of a country that would be in better conditions, with more efficient public serves for hosting the event, was broken. The participants expressed that expectations that had not been met.

\section{Distrust and the federal government's degree of responsibility}

In addition to changes in the perception of the World Cup, the low confidence in regard to the use of public resources was predominant in the focus groups. Corruption was not the factor most often remembered; instead, it was frustration at the contrast with what was being spent. And part of this negative vision about this contrast noticeably stemmed from the distrust of the misuse of public resources.

"I think 'the World Cup highlighted all the corruption, all the dirtiness'. It took it all from out under the rug and put it on top. The astronomical expenses and those that weren't spent, saying that it had spent, on the part of those that administered the training - the federal government" (our emphasis) (ANONYMOUS INTERVIEWEE , 2013³0)

"In the Confederations Cup, they [the government] 'took 80 million from education in Minas Gerais', and did it so a bunch of people from other countries would come here, and 'our students didn't have books, materials, computers, Internet, or anything'" (our emphasis) (ANONYMOUS INTERVIEWEE , 2013²1).

"I even think that the government is doing it, but everything it does comes with extra-a slush fund, two slush funds, three slush funds. It finds a way to improve things a bit, but also get something for itself as well. The stadium was really expensive, with many millions passed on to them [the politicians]" (ANONYMOUS INTERVIEWEE , 2013²).

When Norris (2011) writes about skepticism of public governance, directed toward specific government policies and actions, she argues that this is one of the symptoms of contemporary liberal democracies, and that this skepticism, unlike apathy, generates new forms of unconventional public attitudes on

\footnotetext{
${ }^{30}$ Belo Horizonte, World Cup Climate, AB, 35-50, female.

${ }^{31}$ Belo Horizonte, Copa II, AB, 18-26, bad/terrible.

${ }^{32}$ Brasília, Copa II, CD, 18-25, good/excellent.
} 
participation. According to Norris (2011), people react to frustrated expectations with increased levels of criticism. This was what we found in the group discussions: criticisms as a symptom of this frustration. Brazilians' lack of confidence certainly impacted indices of support for the World Cup and the federal government. In various quotations, it was possible to notice the participants' indignation. Many even showed a certain cynicism about suspected misuses of public resources.

"I think we should become a more socially just country, with more social equality, income distribution, and when a World Cup happens, who's going to bear the costs? The debt from building stadiums, 'we know how corruption works, the diversion of money, overbilling, we're going to have to bear the costs of it' (our emphasis) (ANONYMOUS INTERVIEWEE, 201333).

"This was the worst government I've ever seen. They brought the World Cup here thinking that they were going to hide this, and they shot themselves in the foot. 'They could have not stolen so much and have done more things for the people'" (our emphasis) (ANONYMOUS INTERVIEWEE, 201334).

The level of distrust became quite evident in the discussions of the focus groups. The lack of faith of Brazilians not only had to do with the use of public money, but also the government's capacity to deliver what it had promised. One of the most common phrases heard in the streets before the World Cup was 'if it's like this now, imagine during the World Cup'. Add to this that people attributed most of the responsibility, in both the quantitative and qualitative tests, for the problems linked to and caused by the World Cup to the federal government.

\section{Public services versus the World Cup: increases in criticism}

One of the noticeable points of the focus group discussions was the spontaneous and direct association between the World Cup and public services. This is one of the most important paths for understanding how the federal government's performance achieved such notoriety, making it a cognitive shortcut. This has to do, above all, with the perception of the product of government action in the preparation for the World Cup and the comparison with public services in general.

\footnotetext{
${ }^{33}$ Salvador, Copa I, CD, 40-55, bad/terrible.

${ }^{34}$ São Paulo, World Cup Climate, AB, 18-26, male.
} 
As we see it, the relationship between the World Cup and public services, which already emerged in the quantitative analysis, is confirmed.

"They 'are associating it, rightly, with health care; you go to the hospital and there aren't any doctors, but there's money for the World Cup. You become against it because you begin to associate it with other topics'. They don't pay the minimum wage for teachers, but they have money for the World Cup" (our emphasis) (ANONYMOUS INTERVIEWEE, 20135).

Since Ancient Rome, they've treated the people to parties and games. And if we're going to analyze it once more, with all these social problems, we're worrying about investing millions and billions in a beautiful party but that will only be shutting us up for a few moments so we forget our problems. 'The World Cup will be over and all these problems will continue. There will be stadiums from these billions where they could be quality hospitals and schools' (our emphasis) (ANONYMOUS INTERVIEWEE, 20136).

"The World Cup is stealing our education." "Brazil needs health care, not a World Cup." "'Invest in me and call me 'World Cup'" (our emphasis) (ANONYMOUS INTERVIEWEE, 201337).

"I never thought that the World Cup was for Brazilians, because 'Brazilians aren't thinking about soccer, they're thinking about health care and education'" (our emphasis) (ANONYMOUS INTERVIEWEE, 2013³8)

"'It shouldn't be invested in the World Cup, but rather in health care'. I know lots of people who have died because there wasn't an ICU. So 'it's outrageous that, in Brazil, people cannot be attended to because the government doesn't have money for health care and they're making stadiums'" (our emphasis) (ANONYMOUS INTERVIEWEE, 2013³).

\section{Perception of the legacy and its impacts}

The vision of the legacy is one of the pillars of residents' formation of support in host cities for sporting mega-events (GURSOY and KENDALL, 2006; KIM et al., 2006; PRAYAG et al., 2013; RITCHIE et al., 2010). In Brazil, however, the

\footnotetext{
35Porto Alegre, Copa II, AB, 40-55, good/excellent.

${ }^{36}$ Manaus, Copa II, AB, 30-39, bad/terrible.

${ }^{37}$ Belo Horizonte, Copa I, AB, 18-26.

${ }^{38}$ Natal, Copa II, CD, 30-39 fair.

${ }^{39}$ Brasília, Copa II, AB, 40-55, bad/terrible.
} 
countless problems that emerged during the preparation for the games began to, little by little, call this hope for a positive legacy into question. This becomes clear in the quotations below, in response to the following question, asked in the World Cup Climate study that was conducted on the eve of the event: Do you think that the benefit and harm are equal, that the benefits are greater, or that the amount of harm is greater?

I see a lot of benefits, but I think that we are no longer winning with this World Cup; I think that we didn't need to have a World Cup in Brazil now. 'I think that there are things that are much more important than a World Cup in Brazil: investments in hospitals, investments in education'... There are many more things that need more investment than the World Cup (our emphasis) (ANONYMOUS INTERVIEWEE, 2013 ${ }^{40}$ ).

'The harm will have more of an effect'. They've already begun to increase taxes. There was a benefit, yes, 'but we thought there would be more'. We thought that the subway system would go to Savassi, yet the subway never got off the ground. Move [the rapid bus transportation system] is good, and it will help, but the subway would be much better (our emphasis)(ANONYMOUS INTERVIEWEE, 2013²).

In the year that the World Cup started here, in 2012, in January, I was listening to the radio in Gazeta, and the [inaudible] placed a message that was so beautiful, asking for us to be calm and have patience because they were going to be two difficult years of works, but that, if we worked together...so, what she said got stuck in my head, 'but we were disappointed and frustrated. I think that for our city, the harm outweighed the benefits' (our emphasis) (ANONYMOUS INTERVIEWEE, $2013^{42}$ ).

One factor that draws attention is that people do not talk only about material losses, or the despair about what the World Cup would bequeath to Brazil. They saw all the attrition suffered throughout the process as 'harm', and made the constant association that it had stopped being invested in basic public services. The vision of the legacy transcended the works that were left behind. They involved everything from the use of resources to the day-to-day effects, and even the resources no longer being spent in other areas.

At the beginning, no one cared about the chaos of the works, because 'everyone believed that it would turn out well', and no one

\footnotetext{
${ }^{40}$ Belo Horizonte, World Cup Climate, AB, 18-29, male.

${ }^{41}$ Belo Horizonte, World Cup Climate, AB, 35-50, female.

${ }^{42}$ Cuiabá, World Cup Climate, AB, 18-26, female.
} 
cared about riding the bus, almost dying inside it, because they knew it would turn out well. It's just that time passed, the things that were being promised were not being delivered, and the city was becoming uglier and more chaotic, 'it was disappointing, losing its appeal, and it was disillusioning us'. It gave us the sensation that they were making fools of us during these two whole years. (our emphasis) (ANONYMOUS INTERVIEWEE, 2013 ${ }^{43}$ ).

The big hit was in badly invested money, and in works that were supposed to be finished, but weren't. The most harm was done by badly invested money, works that were supposed to be finished, but weren't, and urban mobility. Who is also losing, and this isn't in physical funding, but indeed virtual funding, is the people. 'Brazil loses on the question of health care, education, on the part of the schools' (our emphasis) (ANONYMOUS INTERVIEWEE, 2013 ${ }^{44}$ ).

"You get indignant with the lack of investment in other things. We need a subway system, among other things; 'the stadium is superfluous'. (our emphasis) (ANONYMOUS INTERVIEWEE, 2013 ${ }^{45}$ ).

"I think that it is a matter of pride, of you feeling like you've been tricked. There are so many things that we need. We see people dying, you're being robbed. It's the facade. The loss of money. 'And we see that the country is capable of hosting a World Cup, but not of giving us a good life'" (our emphasis) (ANONYMOUS INTERVIEWEE, $2013^{46}$ ).

Obviously, some of the participants defended the World Cup and believed in the actions of the federal government. This positive vision, however, was not predominant. Next to the feeling of happiness that is often attributed to Brazilians, there was frustration and disappointment. The people made a distinction between their opinions on soccer, the event itself, and the actions of the government. On the whole, one could see that questions related to governance mattered more. In other words, participants did not seem very worried about whether Brazil would win or lose on the field, but instead demonstrated an almost obsessive association between the World Cup and the situation of the country. Once more, the World Cup was serving as a shortcut for reflections on one's own reality.

\footnotetext{
${ }^{43}$ Cuiabá, World Cup Climate, AB, 18-26, female.

${ }^{44}$ Manaus, World Cup Climate, CD, 18-26, male.

${ }^{45}$ São Paulo, World Cup Climate, CD, 35-50 years, male.

${ }^{46}$ Salvador, World Cup Climate, CD, 18-26, male.
} 


\section{Conclusion}

There is no doubt that sporting mega-events such as the World Cup and the Olympic Games are politically important (GRIX and HOULIHAN, 2013). This, however, does not mean that political science is a discipline where there are various studies on the topic. Despite the immense role that sports has on money, power, and public policy-both nationally and internationally-"political science literature, however, focuses remarkably little on sports" (GIFT and MINER, 2017, p. 129).

The literature about sports and politics suggest that sporting mega-events are capable of elevating nationalist feelings, fostering national unity, increasing the international importance of host cities, and adding value to the rulers' political capital. In this sense, its political use could be seen as a good strategy for increasing popular support. In practice, though, this is not what happened in Brazil with the World Cup in 2014. In this article, we sought to understand exactly how the popularity of the Brazilian government was affected by holding the World Cup in the country.

The data analyzed, both quantitative and qualitative, showed the presence of feelings of frustration among the negative evaluations of public services and the expectations created for having a better country. With the arrival of the World Cup on the horizon, mainly from the Confederations Cup on, in 2013, people began to present more critical positions, using the sporting mega-event as a reference for evaluation and a shortcut for reflecting on the standard of public services and government performance. As a result, one can state that the FIFA World Cup put the performance of the federal government on show, not only regarding the preparation of the tournament, but also for conducting public policy. It is interesting to note that, from the point of view of the literature on sports and politics, these relationships occur independently of the results of the national soccer team of Brazil, because all the data presented in this article were obtained before the beginning of the tournament.

The emergence of the World Cup as a reference for evaluating the government can be better understood in light of theories such as that of the citizenevaluator (OSTROM JR. and SIMON, 1985) and categories such as critical citizens (NORRIS, 2011). The phenomenon links, above all, with what is predicted in the theory of rally events. As such, we conclude that, in fact, there was a negative rally 
effect on presidential popularity between 2013 and 2014, that was motivated by the World Cup.

From the political point of view, sporting mega-events can call into question the popularity of political representatives, especially in liberal democracies, where actors such as public opinion have more participation. The interference in the sovereignty of Brazil, the extensive visibility of the World Cup in the media, the considerable sums of public money spent, the far-from-transparent relationships between contractors and political groups, and the increase in criticism on the part of the public all led people to believe that rulers must think with caution upon mortgaging their popularity by hosting the World Cup and Olympics.

Translated by Ryan Lloyd Submitted on August 31, 2018 Accepted on April 06, 2019

\section{References}

ALMEIDA, Bárbara Schausteck de; BOLSMANN, Chris; MARCHI JR., Wanderley, and SOUZA, Juliano de (2015), Rationales, rhetoric and realities: FIFA's World Cup in South Africa 2010 and Brazil 2014. International Review for the Sociology of Sport. Vol. 50, № 03, pp. 265-282.

ANONYMOUS INTERVIEWEE, (2013), Assessoria de Opinião Pública SECOM/PR. Belo Horizonte, Brasília, Cuiabá, Manaus, Natal, Porto Alegre, Salvador, São Paulo. Available at < https://doi.org/10.7910/DVN/XS9HSO $>$. Accessed on April, 14, 2018.

ARNAUD, Pierre (1998), Sport-a means of national representation. In: Sport and international politics: the impact of fascism and comunism on sport . Edited by ARNAUD, Pierre and RIORDAN, James. London and New York: E \& FN SPON. pp. 03-13.

BAILEY, Kyle; OLIVER, Robert; GAFFNEY, Christopher, and KOLIVRAS, Korine (2017), Negotiating 'new' narratives : Rio de Janeiro and the 'Media Geography' of the 2014 FIFA World Cup. Journal of Sport and Social Issues. Vol. 41, № 01, pp. 70-93.

BERLEMANN, Michael and ENKELMANN, Sören (2014), The economic determinants of U.S. presidential approval: a survey. European Journal of Political Economy. Vol. 26, issue C, pp. 41-54.

BONDE, Hans (2009), Danish sport and the nazi seizure of power: indoctrination, propaganda and confrontation. The International Journal of the History of Sport. Vol. 26, № 10, pp. 1458-1480. 
BORSANI, Hugo (2001), Eleições e desempenho macroeconômico na América Latina (1979-1998). Dados. Vol. 44, № 03, pp. 481-512.

BOYKOFF, Jules (2011a), Fun at the games: the anti-Olympics. New Left Review. Vol. 67, pp. 41-59.

BOYKOFF, Jules (2011b), Space matters: the 2010 Winter Olympics and its discontents. Human Geography. Vol. 04, № 02, pp. 48-60.

BOYKOFF, Jules and FUSSEY, Peter (2014), London's shadow legacies: security and activism at the 2012 Olympics. Contemporary Social Science. Vol. 09, № 02, pp. 253-270.

BRINGEL, Breno and PLEYERS, Geoffrey (2015), Junho de 2013... dois anos depois: Polarização, impactos e reconfiguração do ativismo no Brasil. Nueva Sociedad. Vol. 259, pp. 04-17.

BUROCCO, Laura (2014), África do Sul. In: Copa para quem e para quê? Um olhar sobre os legados dos mundiais no Brasil, África do Sul e Alemanha. Edited by PAULA, Marilene de and BARTELT, Dawid Danilo. Rio de Janeiro: Fundação Heinrich Böll. pp. 60-105.

CHONG, Dennis (1993), How people think, reason, and feel about rights and liberties. American Journal of Political Science. Vol. 37, № 03, pp. 867-899.

CARLIN, Ryan E.; HARTLYN, Jonathan; HELLWIG, Timothy; LOVE, Gregory J.; MARTINEZ-GALLARDO, Cecilia, and SINGER, Matthew M. (2016), Executive approval database 1.0. Available at $\langle w w w . e x e c u t i v e a p p r o v a l . o r g\rangle$. Accessed on April, 14, 2108.

COTTLE, Eddie (2014), Copa do Mundo na África do Sul: um legado para quem? Florianópolis: Insular. 408 pp..

COTTLE, Eddie (2011), South Africa's World Cup: A Legacy for Whom? South Africa: University of KwaZulu-Natal Press. 368 pp..

DAMATTA, Roberto (1986), Futebol: ópio do povo X drama de justiça social? In: Explorações: ensaios de sociologia interpretativa. Rio de Janeiro: Rocco. pp. 101-120.

DOMINGUES, Edson Paulo; BETARELLI JR., Admir Antonio, and MAGALHÃES, Aline Souza (2011), Quanto Vale o Show? Impactos Econômicos dos Investimentos da Copa do Mundo 2014 no Brasil. Estudos Econômicos. Vol. 41, № 02, pp. 409-439.

DOWNS, Anthony (1999), Uma teoria econômica da democracia. São Paulo: EDUSP. $336 \mathrm{pp}$. 
DRUMOND, Maurício (2009), Vargas, Perón e o esporte: propaganda política e a imagem da nação. Estudos Históricos. Vol. 22, № 44, pp. 398-421.

EDWARDS III, George C.; MITCHELL, William and, WELCH, Reed (1995), Explaining presidential approval: the significance of issue salience. American Journal of Political Science. Vol. 39, № 01, 108-134.

FARIA, Raquel Macedo Batista de (2016), As manifestações de 2013 e de 2014: enunciações cristalizadas de um perfil de brasilidade. Master's dissertation. Programa de Pós-Graduação em Estudos de Linguagem. Universidade Federal Fluminense.

FIORINA, Morris P. (1981), Retrospective voting in American nacional elections. News Haven and London: Yale University Press. 249 pp..

GERRING, John (2007), Case study research: principles and practices. Cambridge: Cambridge University Press. 265 pp..

GIFT, Thomas and MINER, Andrew (2017), Dropping the ball: the understudied nexus of sports and politics. World Affairs. Vol. 180, № 01, pp. 127-161.

GRAMACHO, Wladimir G. (2014), A pesquisa governamental de opinião pública: razões, limites e a experiência recente no Brasil. Revista do Serviço Público. Vol. 65 , № 01 , pp. 49-64.

GRIX, Jonathan and HOULIHAN, Barrie (2013), Sports mega-events as part of a nation's soft power strategy: the cases of Germany (2006) and the UK (2012). British Journal of Politics and International Relations. Vol. 16, № 04, pp. 572-596.

GURSOY, Dogan and KENDALL, K. W. (2006), Hosting mega events: modeling locals' support. Annals of Tourism Research. Vol. 33, № 03, pp. 603-623.

GUTTMANN, Allen (2003), Sport, politics and the engaged historian. Journal of Contemporary History. Vol. 38, № 03, pp. 363-375.

HEALY, Andrew J.; MALHOTRA, Neil, and MO, Cecilia Hyunjung (2010), Irrelevant events affect voters' evaluations of government performance. Proceedings of the National Academy of Sciences of the United States of America. Vol. 107, № 29, pp. 12804-12809.

KELLY, Jana Morgan (2003), Counting on the past or investing in the future? Economic and political accountability in Fujimori's Peru. The Journal of Politics. Vol. 65, № 03, pp. 864-880.

KERNELL, Samuel (1978), Explaining presidential popularity: how ad hoc theorizing, misplaced emphasis, and insufficient care in measuring one's variables refuted common sense and led conventional wisdom down the path of anomalies. American Political Science Review. Vol. 72, № 02, pp. 506-522. 
KIEWIET, D. Roderick (1983), Macroeconomics and micropolitics: the electoral effects of economic issues. Chicago and London: The University of Chicago Press. $176 \mathrm{pp}$.

KIM, Hyun Jeong Jenny; GURSOY, Dogan, and LEE, Soo-Bum (2006), The impact of the 2002 World Cup on South Korea: comparisons of pre- and post-games. Tourism Management. Vol. 27, № 01, pp. 86-96.

KIM, Samuel Seongseop and PETRICK, James F. (2005), Residents' perceptions on impacts of the FIFA 2002 World Cup: the case of Seoul as a host cit. Tourism Management. Vol. 26, № 01, pp. 25-38.

KINDER, Donald R. (1981), Presidents, prosperity, and public opinion. Public Opinion Quarterly. Vol. 45, № 01, pp. 01-21.

KING, Gary; KEOHANE, Robert O., and VERBA, Sidney (1994), Designing social inquiry: scientific inference in qualitative research. Princeton: Princeton University Press. 264 pp..

KROSNICK, Jon A. and BRANNON, Laura A. (1993), The impact of the Gulf War on the ingredients of presidential evaluations: multidimensional effects of political involvement. American Political Science Review. Vol. 87, № 04, pp. 963-975.

KROSNICK, Jon A. and KINDER, Donald R. (1990), Altering the foundations of support for the president through priming. American Political Science Review. Vol. 84, № 02, pp. 497-512.

LEWIS-BECK, Michael S. and STEGMAIER, Mary (2013), The VP-function revisited: a survey of the literature on vote and popularity functions after over 40 years. Public Choice. Vol. 157, № 03, pp. 367-385.

MOISÉS, Arce E. (2003), Political violence and presidential approval in Peru. The Journal of Politics. Vol. 65, № 02, pp. 572-583.

MOISÉS, Arce E. and CARRIÓN, Julio F. (2010), Presidential support in a context of crisis and recovery in Peru, 1985-2008. Journal of Politics in Latin America. Vol. 02, № 01, pp. 31-51.

MUELLER, John E. (1970), Presidential popularity from Truman to Johnson. American Political Science Review. Vol. 64, № 01, pp. 18-34.

MUTZ, Diana C. (1994), Contextualizing personal experience: the role of mass media. The Journal of Politics. Vol. 56, № 03, pp. 689-714.

NADEAU, Richard; NIEMI, Richard G.; FAN, David P. and, AMATO, Timothy (1999), Elite economic forecasts, economic news, mass economic judgments, and presidential approval. The Journal of Politics. Vol. 61, № 01, pp. 109-135. 
NANNESTAD, Peter and PALDAM, Martin (1994), The VP-function: a survey of the literature on vote and popularity functions after 25 years. Public Choice. Vol. 79, № 03-04, pp. 213-245.

NEWMAN, Brian and FORCEHIMES, Andrew (2010), 'Rally round the flag' events for presidential approval research. Electoral Studies. № 29, pp. 144-154.

NOLL, Roger G. (1995), Downsian thresholds and the theory of political advertising. In: Information, participation, and choice: an economic theory of democracy in perspective. Edited by GROFMAN, Bernard. Ann Arbor: The University of Michigan Press. pp. 37-55.

NORRIS, Pippa (2011), Democratic deficit: critical citizens revisited. Cambridge: Cambridge University Press. 350 pp..

OSTROM JR., Charles W. and SIMON, Dennis M. (1989), The man in the Teflon suit? The environmental connection, political drama, and popular support in the Reagan presidency. Public Opinion Quarterly. Vol. 53, № 03, pp. 353-387.

OSTROM JR., Charles W. and SIMON, Dennis M. (1985), Promise and performance: a dynamic model of presidential popularity. American Political Science Review. Vol. 79, № 02, pp. 334-358.

PENNA, Adriana (2013), Megaeventos esportivos no Brasil: raias abertas para a corrida do capital. O Social em Questão. Ano XVI, № 29, pp. 209-234.

PRAYAG, Girish; HOSANY, Sameer; NUNKOO, Robin, and ALDERS, Taila (2013), London residents' support for the 2012 Olympic Games: the mediating effect of overall attitude. Tourism Management. Vol. 36, pp. 629-640.

QUARTERLY PUBLIC OPINION POLL (2014), Secom/PR. Available at $<$ http://www.secom.gov.br/atuacao/pesquisa/lista-de-pesquisasquantitativas-e-qualitativas-de-contratos-atuais/relatorio-final-pesquisaqualitativa-2013-pre-copa-do-mundo-abr-14.pdf/view>. Accessed on April, 14, 2018.

RITCHIE, Brent W.; SHIPWAY, Richard, and CHIEN, Monica (2010), The role of the media in influencing residents' support for the 2012 Olympic Games. International Journal of Event and Festival Management. Vol. 01, № 03, pp. 202219.

SIGOLI, Mário André and DE ROSE JUNIOR, Dante (2004), A história do uso político do esporte. Revista Brasileira de Ciência e Movimento. Vol. 12, № 02, pp. 111119.

SINGER, André (2013), Brasil, Junho de 2013: classes e ideologias cruzadas. Novos Estudos CEBRAP. Vol. 97, pp. 23-40. 
VINOKUR, Martin Barry (1988), More than a game: sports and politics. Santa Barbara: Greenwood Press. 169 pp..

WAITT, Gordon R. (2003), Social impacts of the Sydney Olympics. Annals of Tourism Research. Vol. 30, № 01, pp. 194-215.

WILLIAMS, Richard (2012), Using the margins command to estimate and interpret adjusted predictions and marginal effects. The Stata Journal. Vol. 12, № 02, pp. 308-331. 